\title{
Proposed Strategic Mandates for Ontario Universities: An Organizational Theory Perspective
}

\author{
Michael Buzzelli \\ University of Western Ontario \\ University of Bologna \\ Derek J. Allison \\ University of Western Ontario
}

\begin{abstract}
This paper presents an empirical analysis of the Ontario-led strategic mandate agreement (SMA) planning exercise. Focusing on the self-generated strategic mandates of five universities (McMaster, Ottawa, Queen's, Toronto, and Western), we asked how universities responded to this exercise of strategic visioning? The answer to this question is important because the SMA process is unique in Ontario, and universities' responses revealed aspects of their selfunderstanding. We adopted an organizational theory approach to understand the structure and nature of universities as organizations and explored how they might confront pressures for change. Analysis of the universities' own proposed strategic mandates found elements of both conformity and striking differentiation, even within this sample of five research-intensive university SMAs. Directions for further work on this planning exercise and on higher education reform more generally are discussed.
\end{abstract}

\section{Resumé}

Cet article propose une analyse empirique de l'exercice de planification de l'accord sur le mandat stratégique dirigé par l'Ontario. En nous penchant sur les mandats stratégiques autogénérés de cinq universités (McMaster, Ottawa, Queen's, Toronto et Western), nous nous demandons quel a été l'effet de cet 
exercice de vision stratégique sur ces universités. La réponse à cette question est d'une grande importance puisque le processus d'accord sur le mandat stratégique est unique en Ontario. Pour les universités, les effets relevés ont révélé des aspects de leur propre compréhension. Pour comprendre la structure et la nature des universités en tant qu'organisations, nous adoptons une approche organisationnelle axée sur la théorie, et étudions comment ces institutions pourraient affronter la pression du changement. Une analyse des mandats stratégiques proposés par les universités révèle des éléments de conformité ainsi qu'une différenciation frappante, même au sein de cet échantillon de cinq accords sur le mandat stratégique d'universités axées sur la recherche. En outre, l'article donne des directives quant aux travaux subséquents relatifs à l'exercice de planification, plus précisément quant à une réforme en enseignement supérieur.

\section{Introduction}

Reform in higher education can be difficult to analyze and understand because multiple pressures for change push against the complexity of systems and institutions (Axelrod, Trilokekar, Shanahan, \& Wellen, 2013). In Canada, the belated arrival of various reform discourses and processes (Jones, 2004) is set against a relatively placid policy environment of earlier post-World War II decades. Early development of the postsecondary system proceeded on the foundation of a social contract in which "the university" was understood to be a public good (Axelrod, 2002; Fallis, 2009). Yet, like the broader public sector (Le Grand, 2003; Mishra, 1990), we have recently seen greater scrutiny of the nature, role, administration, and financing of institutions of higher education, including universities. We draw on recent literature on higher education and organizational theory to understand how a selection of Ontario's research-intensive universities are responding to pressures for change from a key stakeholder and funder, Ontario's Ministry of Training, Colleges and Universities (MTCU).

Acknowledging Canada's delayed and comparatively subtle adoption of recent reforms, Schuetze and Bruneau (2004) argue that policy borrowing in postsecondary education arrived by the mid-1990s and brought with it elements of managerialism and tightened institutional control. Similar conclusions were shared by Kirby (2007) in a review of several reports on higher education in British Columbia, Alberta, Ontario, and Newfoundland and Labrador. Those reports, he argued, "demonstrate the pervasive influence of economic globalization which is accompanied by an increasingly utilitarian, market-oriented ideological outlook" (Kirby, 2007, p. 2). Schuetze, Bruneau, and Grosjean (2012) affirm these same sorts of trends in Canada more recently, citing provincial priorities for reform across a range of issues such as financing, articulation, admissions, and curriculum. It seems the new public management of accountability reforms of Anglo-American governments in the 1980 and 1990 os (Peters \& Savoie, 2001) had begun to influence the policy discourse of Canadian public universities. The Broadhurst Task Force (Council on University Planning and Analysis, 1993) in Ontario was one of the first attempts to link accountability to institutional performance and thus provides a backdrop to the current strategic mandate process.

In Ontario, the strategic mandate process occurs at a juncture where questions of the nature and role of the university are hastened by a shrinking public purse. In Academic 
Transformation, Clark, Moran, Skolnik, and Trick (2009) argued that the research and teaching structure of the province's baccalaureate university system is fiscally unsustainable. The Drummond Commission, the Commission on the Reform on the Reform of Ontario's Public Services, reinforced and augmented this view and similarly proposed, as one solution, that Ontario pursue greater diversity amongst its universities (Ontario, 2012b). Thus began the province's most recent drive toward a policy of institutional differentiation (Ontario, 2012a).

Over the last several years, Ontario's MTCU has asked each university to articulate its mandate by developing a strategic vision of its mission, credentials, pedagogies, and curriculum (Ontario, 2012a). In September 2012, Ontario's universities were required to fulfil a key step in this process by submitting strategic mandate agreement proposals (SMAs) to the MTCU. This followed an August 7, 2012 letter to all executive heads of all institutions in Ontario from then Deputy Minister Deborah Newman of MTCU, which outlined the SMA process, requested SMA submissions (by September 30, 2012) and provided a template for completion of the submission (Newman, 2012). The template included the following subsections:

1. A brief mandate statement including your institution's three priority objectives;

2. Your institution's own vision and how it speaks to the proposed institutional mandate statement;

3. A description of each of your top three priority objectives. For each priority objective

4. Please describe the following:

a. How achievement of the objective will affect your total enrolment and enrolment mix.

- Enrolment growth by credentials and level of study mix;

- Program approval requests and future program mix; and

- Balance between teaching and research focus.

b. Any distinctive advantage, strength or characteristic of your institution that makes achievement of the objective credible, likely, and desirable.

c. The time frame for achieving the objective, resource allocations or redirections required, and metrics to be used to measure progress towards achieving the objective.

d. Where applicable, the innovative initiatives that your institution is pursuing to improve productivity in administration, teaching, research and learning associated with the objective and any associated costs and resource implications.

e. Any public policy tools that you need to achieve the objective.

f. How this objective correlates to one or more of the government's principles and parameters for higher education, outlined in Appendix A [referring to Ontario 2012a]

In a short period of time the submissions were analysed and used to feed further discussion of system- and institutional-level missions and strategies (Bradshaw, 2013). In 2013, the Higher Education Quality Council of Ontario (HEQCO) convened an expert panel at the behest of MTCU to assess the extent to which the SMAs could achieve the government's priorities for the sector. Accordingly, as HEQCO (2013, p. 5) states in its report that, 
[MTCU] instructed the Higher Education Quality Council of Ontario (HEQCO) to establish a peer review panel to evaluate ... mandate submissions ... for their ability to achieve significant improvements in productivity, quality and affordability through both innovation and differentiation.

In 2014 the final SMA documents were agreed to and signed by each postsecondary education institution and MTCU. It is within this context that this paper is situated, centred on empirical analysis of five Ontario universities' SMA proposals: McMaster, Ottawa, Queen's, Toronto, and Western (selection criteria explained in the Methods section below). For instance, in Western's published final SMA, we read "The term of the SMA is from April 1, 2014, to March 31, 2017. The SMA proposal submitted by the University to the Ministry has been used to inform the SMA and is appended to the agreement" (Ontario, 2014). The process by which the mandates will steer institutional vision, mission and-most critical-funding in the universities appears to be unfolding. How this unfolded in relation to funding in particular was interesting to follow because of Ontario's then-current funding model reform exercise (Ontario, 2015), itself based on reporting of institutional key performance indicators for the sector.

Focusing on the SMA proposals initially submitted by these institutions, we asked, How did universities respond to this exercise in strategic visioning? The answer to this question is important because the SMA process is unique in Ontario; the universities' responses to the SMA process revealed their self-understandings. We adopted an organizational theory approach to answering this question, drawing specifically on institutional theory and the concept of intra-organizational coupling as a framework for understanding how universities respond to external pressures such as the SMA exercise.

\section{The Institutional School and Coupling}

The rich and growing literature on Canadian higher education could benefit from a formal adoption of organizational theory (OT). Broadly defined, OT includes overlapping fields that are sometimes synonymously referred to as "organizational development" and "organizational behaviour," as a guide to research and policy. As we see in this paper, empirical analysis of a range of aspects of higher education can benefit from OT, as we have seen in such other sectors as schooling, military and industry. A useful overview of OT is found in Owens and Valensky's (2007) Organizational Behaviour in Education, which underscores the relative infrequency with which OT has been applied to and in turn benefited from analysis of higher education. One good example of OT applied to higher education is Crain's (2008) analysis of change in American dental education, in which he provides an overview of OT as a field and describes how it may be used to understand and implement change in curriculum models and best practices. Crain also considers how theory may also aid in dealing with important themes such as leadership-a point to which we return in the concluding discussion of our paper.

As a first step toward analyzing Ontario's strategic mandate agreement (SMA) process, our level of analysis is institutional rather than disciplinary or departmental. To appreciate how Ontario's universities responded to the SMA exercise, we must take into account their organizational complexity. A fine line exists between the internal coherence that distinguishes organizations within a sector from those of other sectors such as hospitals in the 
healthcare sector or big box retailers in the commercial sector. While there are evident differences between Canadian public universities, even among those within a single province, as Jones (1997) argued, Canadian universities are essentially nodes within parallel sets of provincial systems. Notwithstanding differences, Canadian universities by and large resemble each other. Accordingly, we may define the Canadian public university (CPU) as an autonomous conglomerate organization funded by public subsidies and clients paying regulated fees, whose primary aims are education and discovery. Interactions between the two key organizational features of a CPU, (a) formal autonomy from and within external policy environments and (b) devolved internal administration within the conglomerate structure of academic divisions and units that constitute its academic core, can be reasonably expected to condition how these universities respond to external pressures. We might guess that this combination of formal autonomy and conglomerate structure make the CPU less adaptable to accountability edicts. Other government agencies and corporations that appear to be less democratically run may indeed be more responsive to policies and programs aimed at bringing about specific changes and desired outcomes.

Within the university, it is important to consider how its principal organizational subsystems, that is, its administrative and academic cores, may operate in unison toward a common goal. Within the academic or technical core where the distinctive work of the organization is accomplished, activity is fundamentally creative. Formally legitimated and hierarchically ordered authority usually plays a minor role, except perhaps in times of crisis. As suggested by human relations and human organization theories, these kinds of internal organizational connections can be "characterized by a commitment to mutually shared objectives, high levels of trust, respect, satisfaction from work, and authentic relationships" (Owens \& Valensky, 2007, p. 119). And yet, outmoded methods of neoTaylorist administration can fuel belief in tight management controls and oversight, despite the craft basis of the CPU's educative functions (Gronn, 1982). As McGregor (1978) told us forty years ago, human organizations are open social systems, and we should not expect to be able to "calibrate" their performance as we do with the engineering of durable goods. In the CPU, the nature of these relationships and processes, together with the salience of the CPU's technical (academic) core, characterize the university as "bottom heavy." Hearn (1996) made a similar observation in his study of reforms in USA higher education, arguing that questions concerning the implementation and effectiveness of reforms often arrive at the answer, "It all depends" (pp. 144-5).

Contingency, we argue, also applies to the CPU, including in Ontario. A fruitful analytical, way forward is to invoke the concept of coupling to "sensitize" the observer to the structure and nature of Ontario university responsiveness to the SMA exercise, such as it may be (Orton \& Weick, 1990). Figure 1 depicts the broad conceptual frame espoused in this study to understand the ways in which administrative responses to the SMA exercise may or may not translate into functional adaptations within its technical core. This conceptual frame can help us understand the degree to which, if at all, the key organizational subsystems of the CPU are tightly or loosely coupled. A classic example is Meyer and Rowan's (1983) study of the California school system in which administrative policies and institutionalized practices that were intended to promote accountability, paradoxically reduced administrator oversight and control of core teaching and learning activities. Zucker (1987) explains that while this kind of organizational adaptation promotes pre- 
dictable "standard operating procedures," real-world operational efficiency can be easily undermined or diminished. For Perrow (1986), organizations can "sell themselves out" by committing to such processes that paradoxically undermine their mission. Over the longer term, organizations can lose focus on their very purpose and fall victim to mission drift as administrative concerns and introspections predominate.

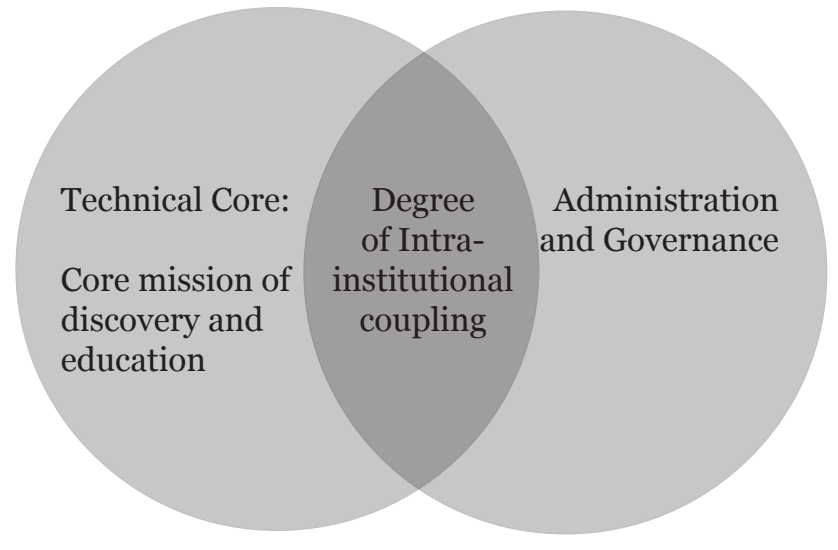

Figure 1. Conceptualisation of Coupling in the CPU

Fallis (2009) evokes the complexity of these internal organizational relations in his notion of the "multiversity" but institutional theory moves us further along. As proposed by Cohen, March, and Olsen (1972) the CPU resembles-indeed it may exemplify-an almost anarchic level of organizational complexity because of its problematic and perennially contested goals, unclear technology, and fluid participation. Formal decision making may be more opportunistic than rational, with popular solutions becoming attached to problems of the day as opportunities arise. As proposed by Cohen et al. (1972, p. 2), within this "garbage can model" of decision making, "many of the axioms and standard procedures of management collapse." As Hearn (1996, p. 145) put it, loose coupling within the organizational structures of USA research universities results in goals that

are rather unclear and sometimes contradictory, [with] poorly understood techniques and systems for achieving those goals, questionable methods for assessing success in meeting those goals, distributed and often decentralized responsibility for decision making, and fluctuating participation in governance activities.

Loose coupling may be a necessary institutional adaptation of the university to the need to continually confront and cope with adaptation and change. If this is correct, the CPU may be innately unsuited to generating the outcomes hoped for in overtly rational activities such as the SMA planning exercise.

Overlaid on and influenced by this internal dynamic is the response we might then expect from universities required to participate in such a rational exercise, which in our case was the content of the SMA documents produced. The late scholar of higher education John Dennison once remarked that universities want two things from their provincial governments: "to be funded and to be left alone" (as noted in Skolnik, 2005, p. 8). One can imagine this traditional posture in the university-as-public-good context of earlier decades. In the present context of openness, accountability, and responsiveness, the SMA exercise implies a more formal contract. 
One way to situate universities' external responsiveness is via institutionalism's distinction between "organization" and "institution." Above, we discussed the potential for complex organizations such as the CPU to adopt normative behaviours for legitimacy and survival. Rather than generating its own path, an organization may imitate its peers. In adopting norms, it may allow its mission to drift and even introduce inefficiency. By contrast, Clark's (1975) concept of "institutional saga," developed about fabled elite USA universities, speaks to the ways in which leading schools exhibit less imitative or normative responses to external pressures. They instead draw on tradition, history (real or idealized "sagas"), and their symbolic leadership to chart a path for themselves, which others may subsequently follow. Increasing turbulence in the form of negotiated and imposed strategic mandates can conceivably generate demands and pressures that separate leaders from imitators.

\section{Methods}

Selected proposed SMAs were analyzed in a multi-step method, focused primarily on document text analysis. ${ }^{1}$ Five universities-McMaster, Ottawa, Queen's, Toronto and Western-were selected for analysis. This group is a hybrid of the "Bovey 6" reference group of research-intensive institutions in Ontario (as originally grouped in the 1984 Ontario Bovey commission on Ontario's research universities which also includes Guelph and Waterloo, not included in the present analysis) and the "medical/doctoral" category employed by Maclean's magazine in its annual national rankings (which includes Ottawa). As noted earlier, the proposed SMAs of the five institutions we analyzed, like all the others in this process, took the form of an eight-page submission (Ontario, 2013) that addressed the university's mission, vision, and objectives for achieving a self-proposed mandate. The submissions were also asked to answer questions about how their objectives would be achieved and how they addressed Ontario's MTCU priorities, specifically on such themes as enrolment, comparative institutional advantages, time frames, and performance metrics.

The universities adopted alternative approaches to how they designed their SMAs. Some worked within the stipulated parameters while others sought to provide further text and information by alternative means, such as linked web pages. Still others exceeded the call with substantial covering letters, appendixes and/or referrals to additional materials on web sites. As described below, document 'cleaning' was therefore necessary to prepare the proposed SMAs (as originally posted at the URL in footnote 1) for this analysis.

The document analysis undertaken for the results reported below began with an initial reading of the five SMAs for a broad overview and comparison. This step framed the analysis by examining the documents for their relative diversity in light of prior reports that portrayed SMA submissions as being characterised more by uniformity than diversity (HEQCO, 2013). This initial reading of the documents also provided a first impression of the potential for intra-institutional coupling between the governance / administrative and academic organizational subsystems, as represented in Figure 1.

The second methodological step involved a quantitative text analysis, starting with descriptive accounts of the text in the documents. Images and other ancillary materials were removed from the documents. For instance, the University of Ottawa SMA contains seven photographs and one large in-text logo. McMaster's document was similarly adorned. Once "cleaned," the five selected SMA documents were formatted for import 
into NVivo software for analysis and interpretation of word frequencies and usage. This was done both for individual SMAs and a composite of the five documents combined to facilitate comparison. To illustrate how the database was constructed, Table 1 displays the frequency counts and percentage share of the 50 most common terms across all five documents. As discussed in more detail below, the "raw" (uncleaned) range of terms found in the documents indicate both the document preparation required for analysis as well as the ways in which key words are coded for the text analysis.

Table 2 presents a descriptive profile of word counts in the documents analyzed. It was necessary to decide which words would be kept for analysis and which should be removed as irrelevant or non-pertinent. We retained words when there was any doubt (nonetheless, we return to the issue of "superfluous" text when we consider some of the document coding immediately below and when discussing the results). Numbers, pronouns, conjunctions, prepositions, and articles were always removed. After this further document cleaning of superfluous terms, we found that the five SMAs averaged a text-only count of 5,139 words. It was notable that there was a substantial range around this average; the longest document (Western's) was twice the length of the shortest (Ottawa's). Here we see the first hint of significant differences emerging between the SMAs. In addition, word diversity, defined as the total number of unique terms within each document, also varied widely about the mean of 1,238 .

A further iteration of the quantitative text analysis was more interpretive and involved coding a subset of the most commonly appearing words in all documents (the 50 most used in each SMA and the 100 most frequently appearing in the composite). Four categories were used to code these high-frequency terms:

1. Terms referring to the technical core, focusing on the teaching, learning, and discovery missions of the university. Any words pertaining to curriculum, pedagogy, programs, credentials, students, and faculty are coded into this category

2. Terms referring to administration (incorporating our focus on coupling). Words related to strategies, goals, objectives, performance, and related terminology such as scorecard, reporting, and evaluation are coded here.

3. Other words that could not be coded into the above two categories but were considered to be relevant are coded here. This category includes words such as place and institutional names.

4. Non-applicable (N/A) indicates words such as articles, conjunctions, adverbs that were not otherwise coded and other items such as dates and numbers.

In general, Table 2 shows that this set of 50 coded high-frequency words typically comprise $4.2 \%$ of all word diversity in the SMAs (3.0\% in the composite document's top 100). These terms make up on average $27.4 \%$ of all words used in the SMAs and $31.8 \%$ of all documents combined. Though the top 50 and 100 high-frequency words are an arbitrary cut-off, it was adopted as a reasonable span of terms to yield an interpretable impression of SMA discourse.

A final step in the analysis sought to provide context to the quantitative exercise outlined above by re-examining the SMA submissions for specific instances where discussion of the technical core and administration (and aspects of coupling in particular) are interconnected. 
Proposed Strategic Mandates for Ontario Universities / M. Buzzelli \& D. J. Allison 178

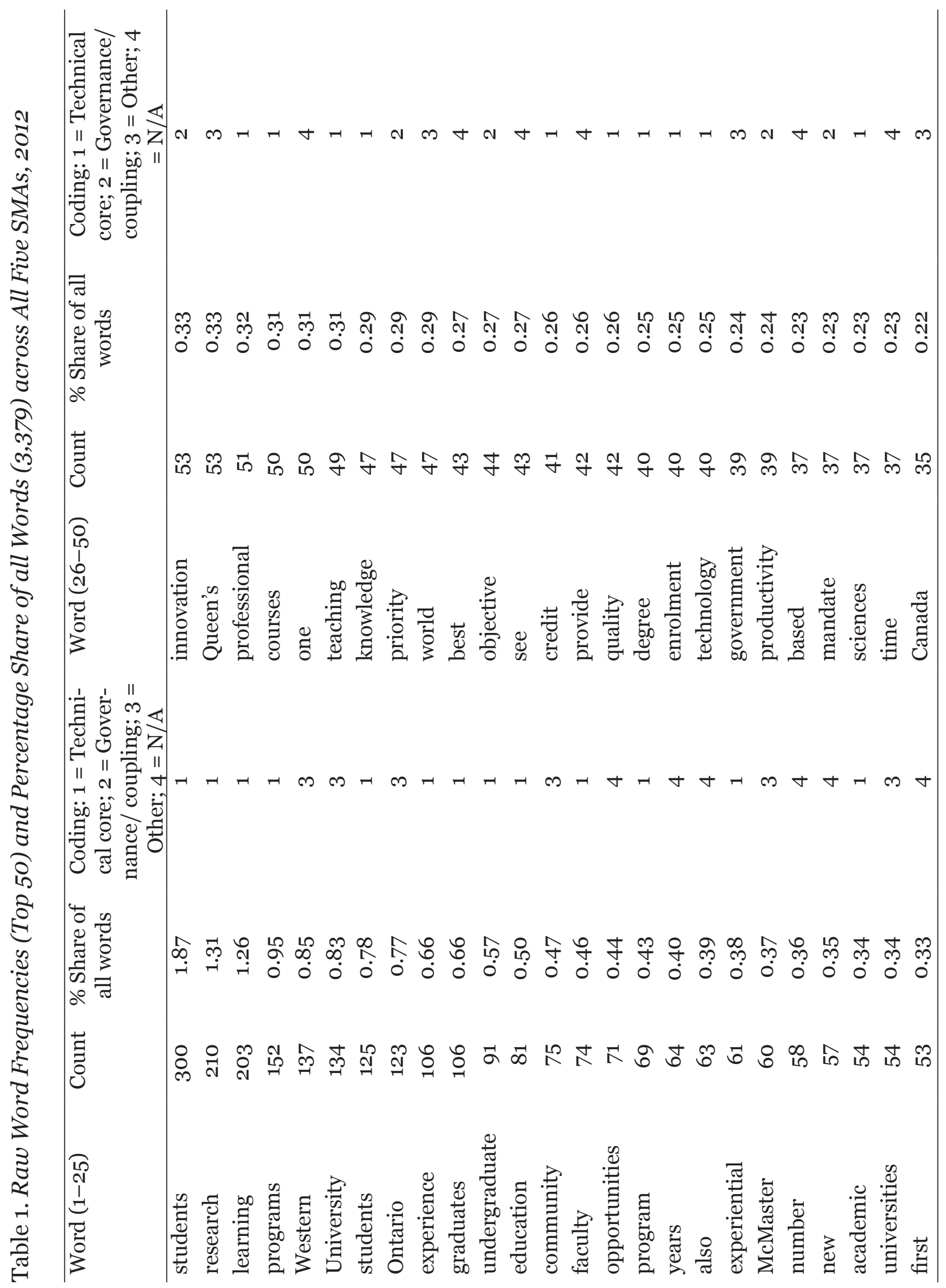


Proposed Strategic Mandates for Ontario Universities / M. Buzzelli \& D. J. Allison 179

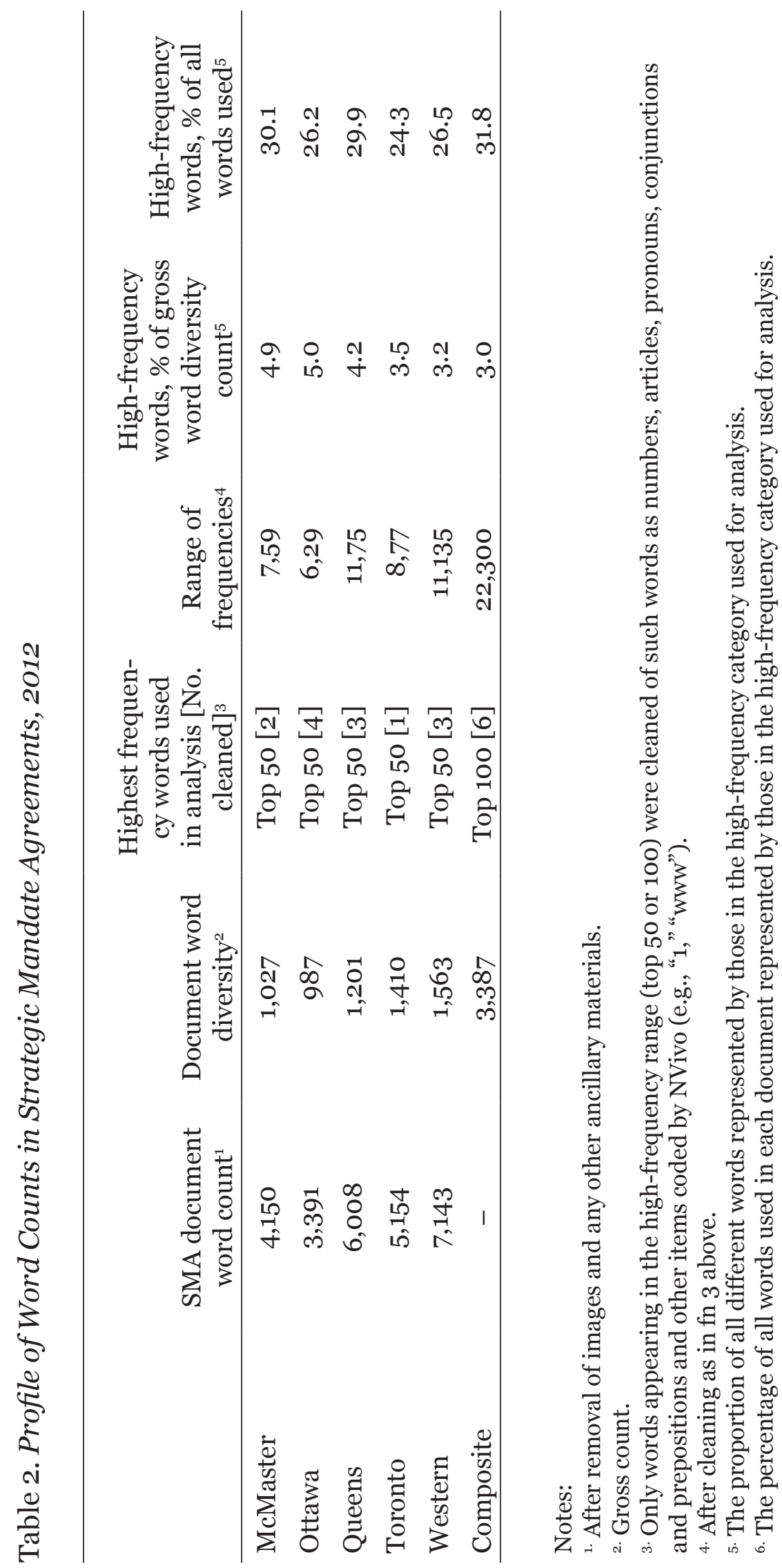




\section{Results}

\section{First Reading and Impressions}

The analysis of the chosen SMAs began with a summary interpretation of each document. A composite interpretation was also developed in an attempt to capture the similarities referred to in the Higher Education Quality Council of Ontario's (HEQCO, 2013) review of the submissions. We reasoned that this claim needed to be assessed as part of our analysis given that (1) the exercise was to focus on institutional vision, proposed mandate, and priority objectives and (2) universities in general will weave scholarship, research, teaching, and learning into these items. In this context, a degree of uniformity might be expected, but a closer analysis might yet reveal differences.

Similarities were noted between the SMAs submitted by Western and Queen's. Each promoted their institutions as offering, respectively, "the best student experience among Canada's leading research-intensive universities" and, with similar phrasing throughout, "the quintessential balanced academy." In contrast, McMaster's SMA submission begins with a more substantial discussion of priorities, innovation, and productivity before enfolding the more familiar discussion of being a "research-focused, student-centred university." But even when discussing central activities, McMaster's submission placed relatively more emphasis on pedagogy, drawing on the university's history in developing inquiry and problem-based learning. Markedly more than the previous two, McMaster's SMA stressed connections with the community as a priority. Within this subset of three, McMaster's foregrounding of governance issues contrasted most with Queen's SMA, which says the least of all the submissions about this. Even Queen's relatively greater emphasis on core technology does not highlight pedagogy to the same extent. Western's SMA reads as having the most traditional flavour, placing relatively more weight on accomplishments and less on governance and future directions. Perhaps it is not surprising that the term "Western" is $3 \%$ of all unique words in the university's SMA document (135 instances), appearing twice as often as the next most frequent term ("students," 1.7\% [78 instances]); "Western" is also the fifth most-frequent term across all five SMAs combined (after "students," "research," "learning," and, "programs").

Though we point to differences between this initial subset of three SMAs, they look more alike when compared to the SMA submissions from Ottawa and Toronto. Ottawa's is unique not only for its brevity and heavy use of visuals but also because of the university's bilingual mandate. Playing to the differentiation objective, its SMA says, "We are unique because of our location in the heart of the nation's capital, our bilingualism and commitment to the promotion of French culture in Ontario, and the excellence of our scholarship" (p. 1). With regard to the latter point-its academic core-the discussion is relatively brief but covers many of the same points we see in the other SMAs including curriculum, credentials, pedagogy, research excellence, and knowledge translation. At the same time, Ottawa's SMA is similar to McMaster's but with even greater emphasis on governance for change. A publicly available "Scorecard" approach is said to have been adopted to monitor progress on developing its priorities and objectives, such as accounting for the adoption of experiential learning opportunities in courses and programs (the Scorecard was submitted to the MTCU, as an appendix to the SMA but not included in the SMA made public). This SMA evokes a feeling quite unlike the others, especially in the 
way bilingualism and distinct governance are promoted as strategic paths forward; all of this over and above the brevity and visual-heaviness of its appearance.

Adding to the diversity of the above four proposed SMAs is the University of Toronto's document. It is similar in some ways to Western and Queen's in identifying accomplishments to date and similar to McMaster and Ottawa in its approach to governance for change. Yet it is unabashed about its research accomplishments (much more so than McMaster) and sets a clearly distinguishing tone with (1) a self-assurance that the university is world-class, thus distinct from all others in the province and ought to be treated as such in the SMA process, and (2) its dominant size and distinctive internal differentiation of enrolment, as manifest in a central Toronto graduate- and research-heavy hub with two suburban primarily undergraduate teaching campuses (Mississauga, Scarborough). Strategically, this SMA gives the impression of hitting all the harmonious notes for a future mandate. Indeed, if one were to identify a SMA submission in this group of five that approaches Zucker's (1986) definition of an institution (rather than a mere organization), it is Toronto's. One is struck by the manner in which Toronto asserts a direction for change not only for itself but also the university system so that it may continue to lead Ontario and Canada. For instance, the Toronto's SMA recommends on page 5 a change to university block-grant funding to account for research performance and an increase in the level of international research-based graduate student funding. Such clear and unambiguous recommendations are unseen in the other documents. In fact, Toronto goes further than any other in suggesting that the SMA exercise itself may need to be refined:

We take up below the invitation to comment on policy issues for priority \# 1 [relating to efficiencies and productivity while sustaining research intensity and enrolment differentiation]. For now, we note that the University has made its first priority a set of measures that address efficiency and productivity. We cannot set targets without clarity about how the Ministry defines productivity . . . Neither the weights for these outputs / outcomes, nor the framework for analysis (e.g., average or marginal measures) has been delineated. We would welcome a conversation to clarify these analytical issues ... (p. 4)

After an initial reading, we can say the five SMAs as a group share some predictable similarities, given both our sample of research-intensive universities and the parameters of the SMA exercise itself. But beyond this familiar ground, we see seeds of some qualitative differences.

\section{Quantitative SMA Text Analysis}

Turning to our second method, the quantitative word frequency analysis summarized above (Table 2) permits us another window on similarities and differences among SMA submissions. Table 3 and the inset figure compare numerical results from the coding exercise. The columns show the counts for the most frequently used 50 words in each university's SMA document, coded into the four analytical categories discussed earlier, the final column was based on the most frequently used 100 words in the composite document. Entries in each column are thus directly comparable, each entry representing the share of

a standardized total. At first blush, the word diversity across all SMAs as collected in the composite shown in Table 3 is nearly triple that or the individual university documents. At 
least quantitatively, this suggests that the documents also varied substantially in writing style and perhaps also content. Our focus is on the first two data rows and corresponding columns in the inset. They reveal that the technical core provides the dominant category of terms in all submissions (tied with "other" for Ottawa), but not for the composite text, where it is second to superfluous text. Words classified as dealing with the technical core averaged 20 of the 50 high-frequency words across the SMA documents, and totalled 32 of the top 100 in the composite. Just as striking is that terms coded into the governance category were least common, averaging only seven of the 50 high-frequency terms across the documents and a proportionate sum in the composite. Upon closer examination of terms like "quality," "productivity," "priority," and "objective," they appeared from 39 to 47 times across all documents combined. Any interpretation based on counts alone should proceed with caution, but some interesting avenues exist. On the one hand, these are relatively low numbers. Given the parameters and purpose of the SMA exercise, one might have expected a greater presence of text and discussion referring to governance and internal coupling. On the other hand, these terms do appear within the high-frequency category and do flavour the SMA submissions.

Table 3. Coding of High-Frequency Words in Ontario University SMA Submissions

\begin{tabular}{lcccccc}
\hline & McMaster & Ottawa & Queens & Toronto & Western & Composite \\
\hline 1. Technical core & 20 & 15 & 24 & 21 & 18 & 32 \\
2. Admin / Coupling & 8 & 5 & 7 & 6 & 7 & 13 \\
3. Other & 11 & 15 & 5 & 11 & 13 & 19 \\
4. N / A & 11 & 15 & 14 & 12 & 12 & 36 \\
\hline
\end{tabular}

Let us consider some examples. As noted earlier, the University of Ottawa's submission was the most identifiably governance-oriented. In its submission the term "Scorecard"the tool it will use to monitor and report progress toward differentiation-ranked only 4oth in the frequency of its appearance, yet it appeared seven times. Frequent referral to this term alone suggests a degree of monitoring (perhaps coupling, as discussed below) that might not otherwise exist in a discussion of the university's technical core. In Western's submission (arguably the least governance focused), terms such as "innovation" (22 instances), "commitment" and "development" (21 each), "objective" (19) and "enrolment" (18) were among the most frequently appearing 24 terms. This tells us nothing about the precise meaning and intent of each word in its context, but the sheer magnitude of these raw counts shows an orientation toward responding to pressures for fiscal sustainability while promoting scholarship and teaching as the raison d'être of the university.

Table 4 and the inset present similar results but show the percentage share of highfrequency words of all terms in the respective documents. What we see here is a further amplification of the stress given to aspects of the technical core, averaging $47 \%$ of highfrequency terms compared with $9 \%$ of terms related to administration / coupling. Based at least on these five documents, what this pattern and the analysis above suggest is that an interpretation of the documents as relatively undifferentiated may be too simple. Exceptions to a focus on core issues of scholarship, and teaching and learning are few. Most notable is Ottawa's submission with only $32 \%$ of high-frequency instances devoted to its 
technical core. The other institutions closely approximate, and drive, the composite picture. Still, substantial differences exist in how the five institutions positioned their mandates relative to past and future directions, how they assert their uniqueness, and how they have chosen to deliver their messages in documents that are remarkably different given the constraints of the SMA exercise.

Table 4. Coding of High-Frequency words in Ontario University SMA Submissions, \% Share

\begin{tabular}{lcccccc}
\hline & McMaster & Ottawa & Queens & Toronto & Western & Composite \\
\hline 1. Technical core & 50.3 & 32.3 & 58.5 & 48.1 & 46.1 & 45.3 \\
2.Admin / Coupling & 9.3 & 6.8 & 10.7 & 8.3 & 10.5 & 9.0 \\
3. Other & 25.5 & 36.3 & 10 & 26.7 & 27.7 & 19.6 \\
4. N / A & 14.8 & 24.4 & 20.7 & 16.9 & 15.6 & 26.1 \\
\hline
\end{tabular}

\section{Re-reading for Coupling}

We overlay this quantitative glimpse at the SMA exercise with a re-reading of the proposed SMA documents. This provides an opportunity to re-examine the submissions for the relative importance of the technical core and governance issues and, more importantly, to look for signs of their intersection.

We begin with Western's submission. Like all others, its SMA discusses its vision, proposed mission, and requisite priority objectives. In introducing the latter in a subsection entitled "Transforming mission, mandate, and vision into reality," Western's SMA document states (p. 2)

Western's achievements are the products of good management including an institutional commitment to integrated planning that links our academic, research, capital and budget plans together in an environment of transparency and accountability through processes and policies that have developed over a long period of time ... We take our responsibility to stakeholders seriously and through our governance structure have developed an accountability framework that includes institutional plans, identification of resource needs and allocations, and various monitoring mechanisms to ensure that we can demonstrate progress towards the fulfilment of our plans.

This statement is as close as the SMA comes to identifying relationships between the university's technical core of scholarship, teaching and learning on one hand and its governance on the other. Coupling is identified, but its nature and extent outlined only in broad terms.

While similar in its focus on students, the Queen's SMA appears different from Western's when read specifically for potential coupling between its technical core and administrative processes. The document is filled with allusions to such connections. On page 1, for instance, a timeline ("by 2018') is given for an expanded set of credentials and experiential and entrepreneurial learning opportunities to be developed. On page 2, Queen's commits to both raising its teaching productivity (via technology-enabled learning) and 
improving students' learning outcomes. These and similar issues are discussed throughout the document although details of how they might be achieved are sparse.

In contrast to other SMAs, Queen's gives its response to questions required in the exercise in an appended table that is also filled with elements of coupling. On page 7 the document states "our new budget model will provide incentives to academic units to create the opportunities for students that are envisaged by the priority objectives, and especially the first [expanding undergraduate credentials]." After noting a number of new and continuing community partnerships to substantiate this point, particularly as they involve experiential learning, the point is made again later on to address the credibility of the stated objectives. Thus a budget tool is identified for achieving an objective, which itself suggests an attempt to introduce a tighter coupling of administration with curriculum (and within this, pedagogy) and credentials.

If Toronto's proposed SMA is qualitatively different, the coupling theme reveals less differentiation from the others. Various loose connections between administration and the institution's academic core are identified throughout. The message identified earlier in relation to defining productivity itself speaks to how the authors of the document believe the university has shown leadership in engaging this exercise and how it proposes to promote productivity measures. Like other institutions, Toronto points to its own past and present internal planning exercises and documents as demonstrating a commitment to the same sorts of goals and objectives as represented by the SMA process. At the same time, if the document is as short on coupling as we have defined it, it may also be because of its selfassuredness as a leader within Ontario and Canada. For instance, on page 1, the SMA identifies global peers (such as Harvard and Oxford), notes its 1992 statement of institutional purpose as an "internationally significant research university," and then declares:

While our Mission is unchanged, the accelerating shifts in our context led the University in 2007 to embark on the most extensive planning exercise in our 180-year history. Towards 2030 took both a shorter- and long-term view of the University's position and strategies. Its coverage ranged from strategic differentiation across the three campuses, to renewal of undergraduate education and modes of managing medium-term fiscal challenges.

Much of the document reads as though the university will continue as it had planned while both addressing SMA priorities and asserting what it also sees as imperatives in higher education, given what it assumes is an unquestioned need for Ontario to recognize the University of Toronto's special status within the system. Whether this provides a tenable explanation or not, it is nonetheless interesting that, though qualitatively different to the other SMAs, Toronto's document seems to shield itself from the purpose of the SMA exercise by pointing to its own charted path and its presumed unique status within the Ontario system.

This brings us to our re-read of our final two SMAs documents-those of Ottawa and McMaster. These are separated here because they go beyond the previous three in identifying links between their administrative and academic cores. We have already noted Ottawa's adoption of a Scorecard tool to monitor progress on various initiatives, something it claims on page 1 as "unique in Canada." Having begun with reference to learning outcomes, the SMA later touches on learning outcome assessment: 
Measuring learning outcomes is a key priority for the University of Ottawa. The uOttawa Scorecard focuses on this challenge in indicators 1.1 (undergraduate learning experience) and 1.6 (graduate). In addition, with the help of our School of Psychology, we have also undertaken to perform the standardized Collegiate Learning Assessment (CLA) for the first time in 2012 to formally assess our students' gain in critical thinking and analytic reasoning skills. HEQCO recommends this tool, and if the experience is conclusive, we would continue to use it in the future. (p. 5)

In this statement we see that the university has leveraged the expertise from within its very own technical core (psychology expertise on testing) to mount an instrument (CLA ${ }^{2}$ ) that will be used to monitor administratively defined progress within that same core. Also significant in Ottawa's SMA submission is its identification of a small set of disciplines for substantive differentiation and specialization. On page 5 it identifies health sciences, science and engineering, and public policy as areas of focus for "comparative advantage." Of course all SMAs note relative strengths but typically do so in an inclusive manner, perhaps so as to not alienate other segments of campus. Though the details are sparse, Ottawa's public identification of this small set of academic areas would surely affect other academic units symbolically and substantially. As noted already, this document is short but this means that the explicit administrative oversight woven into the submission marks it as distinct. Space constrains details but this part of the SMA document evokes a commitment to tighter coupling as the institution embraces change.

Finally, McMaster's SMA submission is both similar to Ottawa's in its use of language that evokes tighter coupling of the university's core and its administration, but at the same time appears different in promoting a mandate more directly grounded in the institution's history and purpose. On page 3, for example, McMaster proposes new funding support from Ontario for the "Experiential Learning Centre, a pilot project to

liberate students from the constraints of traditional programs, changing the ways in which we offer courses and evaluate success, as well as enabling a range of pedagogical innovations . . . This model will allow for significant improvements to quality since students will be engaged in experiential, self-directed, and interdisciplinary learning. It also has the potential to achieve measurable cost savings, which will increase as the numbers of participating Faculties and programs expand. In our experience, particularly in Health Sciences, significant savings have been found ... As part of this project we will measure and evaluate the impact on the student experience and the cost-savings achieved. The knowledge we generate will be scalable and applicable to others in the sector.

The document goes on to discuss a number of new surveys and instruments meant to feed planning for curriculum, pedagogy, and credentials offered. What these elements show is a focus on financial sustainability, conditioning and prompting pedagogic and curricular development, and proposals for change and differentiation. The metrics and instruments identified offer a further indication of a commitment to a tighter coupling of administration with McMaster's core academic activities. Like others, McMaster's own planning will have produced some if not all of these initiatives. The SMA process may well have prompted other initiatives, but surely made explicit to external readers many that may have been planned or in operation already. What this shows is a willingness to em- 
brace a degree of tighter coupling that is less evident in the other documents and almost certainly unfamiliar on the province's university campuses.

\section{Discussion and Conclusion}

The interpretation of the proposed SMA documents analyzed in this paper requires nuance because they exhibit elements of sameness as well as striking differences. Organizational theory tells us that the CPU's conglomerate complexity and formal autonomy might condition imitative and normative content. Thus the terms "students," "research," "learning," and "programs" are the most commonly used in all submissions. Whereas one might not have expected to find much discussion of experiential learning in such documents 20 years ago, every SMA in this analysis identifies the concepts of work-integrated / cooperative / internship / service learning experience as growing and defining features of curriculum, pedagogy, and credentialing. Indeed, so common is this point of emphasis that one wonders whether the SMA exercise may have forced hard thinking about this pedagogy or if this is simply the current fashion. Notable, as well, was the remarkably similar drive toward a "balanced academy" by both Queen's and Western-a balance viewed as unsustainable by some (e.g., Clark et al., 2009), and also implicitly questioned by the SMA exercise itself. From an institutional school sense, there is a good deal that is imitative here.

At the same time, we also see striking differences in the selected universities' selfdefinition and in qualitatively different ways. Different responses to the SMA exercise not only belie theory that predicts sameness and imitation, the responses may also distinguish the CPU and the university system as unique because the policy environment may not elicit desired outcomes. System planning might indeed be more direct and effective in other government sectors, such as hospitals or schools, where goals and outcomes may be more clearly defined and measurable. In our sample, while some relied on tradition, others openly (perhaps ostentatiously) embraced change. Notwithstanding the constraints of the exercise, and indeed alternatives in their core activities, Western and Queen's scarcely paid any attention to the coupling of their administrative and academic cores. One might say that if these self-portrayals provide an even roughly accurate account of internal organizational operations, they are examples of decoupled subsystems.

McMaster and Ottawa were different from the other universities analyzed. McMaster's explicitly linked administrative priorities with academic core initiatives and priorities. Ottawa went further still. Whereas McMaster signalled a degree of coupling by basing its positions upon its "institutional" self-definition, Ottawa relied remarkably little on its history (outside of its distinct bilingualism), instead leveraging its own academic core expertise to achieve administrative and governance commitments. Ottawa exerts a tighter coupling of administrative and academic activities than is evident in any other SMA. Indeed, the tenor of Ottawa's account of its plans for enhanced accountability evokes echoes of the attempts at the tightened measurement-driven coupling pursued in American school systems during the scientific management craze of the 1930s, as exemplified by Cubberly (1934) and documented by Callahan (1962).

Qualitatively different again, we found, is the University of Toronto's proposed SMA. This submission fits Zucker's (1986) notion of generative leadership and does so strategically. The Toronto document appears to buffer its technical core by defining and steering the SMA process to merge with its own charted path. In keeping with the SMA goal of dif- 
ferentiation, the Province is invited by Toronto to protect its only world-class institution by adapting the exercise to Toronto's view of itself and of the Ontario system. Leadership is perhaps even more pronounced when Toronto questions and debates elements of the SMA process with a boldness unlike any other.

As seen through the lens of organizational theory on institutions and coupling, we have several qualitatively different responses to the province-led SMA process. Our small sample of five research-intensive universities makes this insight notable, we argue, and calls for further research. An immediate next step could build upon this analysis with more of the original 20 universities' SMAs, including those outside the research-intensive cluster. This analysis could be extended to similar sorts of documents such as mission statements and other strategic pronouncements that are now standard outputs on campuses in Ontario and Canada. We could extend this approach with comparisons across jurisdictions in Canada (as noted below) and beyond. We have seen similar policy signals in Australia and New Zealand also aimed at making their constituent universities more responsive (Australia Government, 2009; Working Party, 2001) and where the discourse surely generates primary documents awaiting analysis and interpretation.

This kind of work may begin to address whether the SMA exercise in particular and reforms of the CPU in general could be guided by a centrally planned accountability policy. The CPU may work stubbornly against the new public management in some respects and yet conform well in areas. We wonder whether a larger sample size would reveal patterns of successful policy direction, such as within clusters of similar institutions or across subsectors among them (e.g., disciplines, professional schools). If, instead, critical policy studies offer any clues (Le Grand, 2003; Peters \& Savoie, 2001) then exercises like the SMAs might miss their mark. This may be not only because because of institutional recalcitrance but also because of the politics and complexity of central planning itself. As noted earlier, the current government's sector-funding model-reform exercise (Ontario, 2015) may support the goals of the now-signed SMAs or it may aid only some institutions or subsets of goals across institutions. Short of complete alignment, these parallel policy exercises will surely layer the complexity of reforms, this over and above the autonomy and conglomerate nature of institutions of the sector. More fundamentally, as we have seen in other jurisdictions, centrally planned exercises toward differentiation rely on perceptions of institutional sameness that may not be supported under detailed analysis (Moodie, 2014). Perhaps because all universities are involved in research and teaching activities they appear to be imitative, but this may mask important distinguishing features at the sub-institutional level. Hidden from a central-planning gaze, issues arise that lead one to wonder about the extent to which an exercise like the SMA process is self-defeating or even perverse (that is, promotes further conformity) in its outcomes.

Finally, institutional theory and the literature on coupling remind us of the value of the institutional school's thick descriptions embedded in case studies that explore the extent and dialectical nature of interactions among organizational actors (Gronn, 1982; Orton \& Weick, 1990). Inspired by Tuchman's (2009) remarkable ethnography, Wannabe $U$, researchers could engage key actors in the SMA process (Provosts, MTCU staff, HEQCO) or perhaps focus on a particular institution. We argued earlier that the study of (Canadian) higher education and theory stand to mutually benefit by marrying the empirical opportunities with, say, the theme of leadership that is so prominent in OT. 
Given the interest in Canadian university presidents and leadership (e.g., Davison, 2012; Budros, 2002), we argue that OT would offer an important window on this "layer" of institutional dialogue between external organizational pressures and internal responses. Guided by the findings from this analysis, we could ask: did key actors within the University of Ottawa decide to signal to the province that they are willing to relinquish their history and embrace change? Is it true that Western's administrative and academic cores are as disconnected as our analysis suggests? We might even venture to explore whether the University of Toronto is more of a "recalcitrant tool" of public policy, in Philip Selznik's classic phrase, than a compliant recipient of government funds. Thus we may begin to nuance our understanding of coupling within the university with the ways in which different types of leaders in alternative types of universities can promote, mediate, or indeed buffer external influences. Of course Ontario's current experience does not stand alone. This approach applies equally well to the many and varied changes we are witnessing across the provinces, as suggested by the work of Kirby (2007) discussed earlier. Consider what the answers might mean for our understanding of the university in Canada and elsewhere. And might such findings help us to mediate the rationality-versus-indeterminacy tension that pervades organizational research, and which may yet frustrate the entire SMA process? One might imagine so but the answers await empirical tilling.

\section{Notes}

1 The SMA documents were originally available in Fall 2013 for public download at: http://www.heqco.ca/en-CA/About\%20Us/policyadvice/Pages/smas.aspx.

2 The CLA is a standardised test of student learning outcomes that is increasingly common in USA higher education. It was introduced in 2000 by the Council for Aid to Education. See www.cae.org.

\section{Acknowledgements}

We wish to thank Emmanuel Songsore for his assistance with the document text analysis. We also wish to dedicate this article to the late Bob Macmillan, a colleague and friend who sparked interest in this research.

\section{References}

Australian Government (2009) Mission-based compacts for universities. A framework for discussion. Department of Education, Employment and Workplace Relations and Department of Innovation, Industry, Science and Research.

Axelrod, P. (2002). Values in conflict: The university, the marketplace and the trials of liberal education. Montreal, QC/Kingston, ON: McGill-Queen's University Press.

Axelrod, P., Trilokekar, R. D., Shanahan, T., \& Wellen, R. (Eds.). (2013). Making policy in turbulent times: Challenges and prospects for higher education. Montreal, QC/ Kingston, ON: McGill-Queen's University Press.

Bradshaw, J. (September 18, 2013). Specialize or risk losing funding, Ontario tells universities and colleges. Globe and Mail. Retrieved from http://www.theglobeandmail. com/news/national/specialize-or-risk-funding-ontario-tells-universities-and-colleges/ article14393294/) 
Budros, A. (2002). Do university presidents make a difference? A strategic leadership theory of university retrenchment. Canadian Journal of Higher Education, 32(1), 91-124.

Council on University Planning and Analysis (CUPA). (1993). Report of the committee on accountability, performance indicators, and outcomes assessment to the Minister's task force on university accountability (B2011-0003/039(06)-(07)). Archives and Special Collections, University of Toronto, Toronto, Canada.

Callahan, R.E. (1962). Education and the cult of efficiency: A study of the social forces that have shaped the administration of the public schools. Chicago, IL: University of Chicago Press.

Clark, B. (1975). The organizational saga in higher education. In J. V. Baldridge \& T. E. Deal (Eds), Managing change in educational organizations: Sociological perspectives, strategies, and case studies (pp. 55-67). Berkeley, CA: McCutchan.

Clark, I., Moran, G. Skolnik, M.L., \& Trick, D. (2009). Academic transformation: The forces reshaping higher education in Ontario. Montreal, QC/Kingston, ON: McGillQueen's University Press.

Cohen, M. D., March, J. G., \& Olsen, J. P. (1972). A garbage can model of organizational choice. Administrative Science Quarterly, 17(1), 1-25.

Crain, G. (2008). Managing change in dental education: Is there a method to the madness? Journal of Dental Education, 72(10), 1100-13.

Davison, P. L. (2012). A 24/7 public possession: Understanding the dissonance and grace of being a post-secondary leader. Canadian Journal of Higher Education, 42(2), 13-33.

Fallis, G. (2007). Multiversities, ideas and democracy. Toronto, ON: University of Toronto Press.

Gronn, P. C. (1982). Neo-taylorism in educational administration? Educational Administration Quarterly, 18(4), 17-35.

Hearn, J. C. (1996). Transforming US higher education: An organizational perspective. Innovative Higher Education, 21(2), 141-54.

HEQCO (2013). Quality: Shifting the focus. A report from the expert panel to assess the strategic mandate agreement submissions. Toronto, ON: Higher Education Quality Council of Ontario.

Jones, G. A. (1997). Preface. In G.A. Jones (Ed.), Higher education in Canada: Different systems, different perspectives (ix-xi). New York, NY: Garland.

Jones, G. A. (2004). Ontario higher education reform, 1995-2003: From modest modifications to policy reform. The Canadian Journal of Higher Education, 34(3), 39-54.

Kirby, D. (2007). Reviewing Canadian post-secondary education: Post-secondary education policy in post-industrial Canada. Canadian Journal of Educational Administration and Policy, 65(3), 1-24.

Le Grand, J. (2003). Motivation, agency \& public policy: Of knights and knaves, pawns \& queens, London, UK: Oxford University Press. 
McGregor, D.M. (1978). The human side of enterprise. In J. M. Shafritz \& A. C. Hyde (Eds.), Classics of public administration. Oak Park, IL: Moore Publishing.

Meyer, J. W., \& Rowan, B. (1983). The structure of educational organizations. In J.W. Meyer and W.R. Scott (Eds.), Organizational environments: Ritual and rationality (pp. 78-109). Beverly Hills, CA: Sage.

Mishra, R. (1990). The collapse of the welfare state? The welfare state in the 1980 os. In G. Fallis \& A. Murray (Eds.), Housing the homeless and poor. Toronto, ON: University of Toronto Press.

Moodie, G. (2014) How different are higher education institutions in the UK, US and Australia? The significance of government involvement. Higher Education Quarterly, 69(1), 3-36.

Newman, D. (2012). Memorandum to Executive Heads and Presidents, Universities and Presidents, Colleges re. Mandate Agreements Submissions. Toronto, ON: Queen's Park.

Ontario (Province of) (2012a). Strengthening Ontario's centres of creativity, innovation and knowledge. Toronto, ON: Ministry of Training, Colleges and Universities.

Ontario (Province of) (2012b). Commission on the reform of Ontario's public services. Toronto, ON: Queen's Printer.

Ontario (Province of) (2013). Ontario's differentiation policy framework for postsecondary education. Toronto, ON: Ministry of Training, Colleges and Universities.

Ontario (Province of) (2014). Strategic mandate agreement (2014-17) between: Ministry of Training, Colleges and Universities \& Western University. Retrieved from http://www.uwo.ca/ipb/publicaccountability/documents/westernagreement.pdf

Ontario (Province of) (2015). Focus on outcomes, centre on students: Perspectives on evolving Ontario's university funding model. Final consultation report. Toronto, ON: Ministry of Training, Colleges and Universities.

Orton, J. D., \& Weick, K. E. (1990). Loosely coupled systems: A reconceptualization. The Academy of Management Review, 15(2), 203-23.

Owens, R. G. and Valensky, T. C. (2007). Organizational behaviour in education: Adaptive leadership and school reform (9th ed.). Boston, MA/Toronto, ON: Allyn \& Bacon.

Perrow, C. (1986). Complex organizations: A critical essay (3rd ed.). New York, NY: Random House.

Peters, B. G. \& Savoie, D. J. (2001). Introduction in Taking stock: Assessing public sector reforms (pp. 3-19). Montreal, QC/Kingston, ON: McGill-Queen's University Press.

Schuetze, H., \& Bruneau, W. (2004). Less state, more market: University reform in Canada and abroad. The Canadian Journal of Higher Education, 34(3), 1-12.

Schuetze, H., Bruneau, W., \& Grosjean, G. (2012). University governance and reform: Policy, fads and experience in international perspective. London, UK: Palgrave.

Skolnik, M. (2005). The Rae review and the structure of postsecondary education in Ontario. In C.M. Beach (Ed.), A challenge for higher education in Ontario (pp. 7-26). Kingston, ON: John Deutsch Institute for the Study of Economic Policy, Queen's University. 
Tuchman, G. (2009). Wannabe U: Inside the corporate university. Chicago, IL: University of Chicago Press.

Working Party on Charters and Profiles (2001). Report of the working party on charters and profiles. Wellington, New Zealand: Ministry of Education.

Zucker, L. G. (1987). Institutional theories of organization. Annual Review of Sociology, $13,443-464$.

\section{Contact Information}

Michael Buzzelli

Universita di Bologna

University of Western Ontario

mbuzzel@uwo.ca

Michael Buzzelli, B.A. (Hons.), M.A., Ph.D., M.Ed., is an Associate Professor at the University of Western Ontario. After completing graduate work at McMaster University, Michael held academic appointments at UBC and Queen's and has been a visiting scholar at the University of Glasgow and the University of Bologna. He has led several national and international research projects and applied graduate policy training and consulting work. His recent work focuses on higher education system policy and planning as well as research on teaching and learning in higher education.

Derek J. Allison, B.Ed., M.Ed., PhD., is Professor Emeritus, the University of Western Ontario and a Fraser Institute Senior Fellow. Derek began his teaching career in England, before undertaking graduate work at the University of Alberta. He joined the Faculty of Education at Western where he taught education policy and leadership. Research interests centre on the organization and operation of schools, theories of leadership, and the philosophy of inquiry. 